\title{
THE HISTORY OF THOUGHT: PHILOSOPHY IN THE VIEW OF MUSLIM PHILOSOPHERS OF THE MIDDLE AGES
}

\author{
Febta Pratama \\ Education History Studi Program \\ University PGRI Indraprasta Jakarta
}

\begin{abstract}
ABSTRAK
Penelitian ini mencoba untuk melihat bagaimana perkembangan dan perjalanan keilmuan kaum muslim, terutama dalam bidang filsafat. Mendeskripsikan bagaimana para filsuf mempelajari kemudian mengembangkan dan menyebarkan ilmu yang didapat. Metode yang digunakan ialah metode sejarah yang terdiri dari empat tahapan yaitu heuristik, kritik sumber, intepretasi, dan historiograpi. Hasil penelitian menunjukkan bahwa tradisi keilmuan muslim sudah ada sejak zaman kenabian. Masuknya filsafat ke peradaban muslim dimulai saat munculnya kelompok-kelompok keilmuan seperti al khawarijh, muta'zillah, dan Ahlul Sunnah Wal Jammaah. Tradisi keilmuan terutama filsafat dimulai oleh peradaban Islam sejak kejatuhan Bizantyum dan dibangunnya Bait Al Hikmah sebagai tempat untuk menterjemahkan buku-buku dari Yunani. Kemudian tradisi keilmuan filsafat muslim dilanjutkan oleh tokoh-tokoh muslim dan yang juga ahli filsafat seperti Ibnu Sina, Ibnu Rusd, Al Farabi. Filsuf-filsuf inilah yang mengembangkan keilmuan terutama filsafat yang menjadi rujukan filsuf barat pada abad setelahnya.
\end{abstract}

Key word. Filsafat, Filsuf, Muslim

\section{ABSTRACK}

This research tries to see how the development of Muslim scholarship and travel, especially in the field of philosophy. Describes how the philosophers studied then develop and spread the knowledge gained. The method used is the method of history that consists of four phases i.e. heuristics, critique, interpretation, and historiography. The results showed that there was already a Muslim scholarly tradition since the time of the prophetic. The entry of Muslim civilization to the philosophy starts when the emergence of scientific groups such as the Al Khawarijh, Muta'zillah, and Ahl Sunnah Wal Jammaah. The tradition of science especially philosophy started by a civilization of Islam since the fall of Byzantium and rebuilding of Bait Al Hikmah as a place to translate books from Greece. Then the Muslim tradition of scientific philosophy continued by Muslim figures and also philosophers such as Ibn Sina, Ibn Rushd, Al Farabi. It is these philosophers who developed a philosophy of science especially become the reference of Western philosophers in afterwards.

\section{Keyword. Philosophy, Philosophers, Muslim}

\section{PENDAHULUAN}

Ilmu pengetahuan yang dalam bahasa Inggris dikenal dengan Science, dalam bahasa latin disebut Scientia memiliki arti mempelajari atau mengetahui. Sebelum abad 17 Ilmu pengetahuan identik dengan filsafat. Definisi ilmu pengetahuan identik dengan definisi filsafat. Jujun $\mathrm{S}$. Sumiantri mengenai masalah dari ilmu pengetahuan, bagaimana cara mendapatkannya dan nilai guna yang 
ada dapat ditinjau dari filsafat. Jadi Filsafat menjadi induk ilmu pengetahuan. Filsafat ialah cabang ilmu yang mempelajari segala sesuatu yang ada. filsafat merupakan cara berpikir yang kritis, radikal untuk mengetahui sesuatu. Filsafat mula-mula berkembang di daratan Eropa hingga menyebar ke arah timur. Meskipun tidak disangkal pada era yang sama di timur juga berkembang filsafat, terutama di daratan Tiongkok dan India. Filsafat di belahan benua Eropa muncul di daratan Yunani dan Romawi. Hal ini jelas tampak dari munculnya filsuf-filsuf Yunani Romawi. Memasuki Abad pertengahan, perkembangan ilmu pengetahuan di Eropa mengalami kemunduran yang sangat tajam. Hal ini karena pada abad pertengahan atau abad gelap "the dark age" semua unsur kehidupan Eropa di kuasai oleh kaum Gereja yang dogmatik.

Abad gelap di Eropa bukanlah akhir dari kemunduran ilmu pengetahuan. Adanya "Black Hole" atau Lubang hitam dalam perkembangan ilmu pengetahuan Eropa merupakan kesalahan Eropa sendiri yang terlalu di dominasi gereja. Black Hole dibenua Eropa seakan menjadi tanda akhir dari ilmu pengetahuan bangsa Eropa. Dominasi gereja yang terlalu kuat dibenua Eropa menjadikan ilmu pengetahuan sulit mengalami perkembangan bahkan mandeg alias jalan di tempat. Zaman Pertengahan di Eropa yang merupakan abad gelap, justru berbanding terbalik dengan dunia timur, khususnya dunia muslim. Zaman pertengahan Eropa atau abad gelap, didunia muslim justru menjadi zaman keemasan, karena pada zaman ini dunia muslim sedang gemilang dengan ilmu pengetahuannya. Pada zaman ini lahir dan muncul ilmuwan-ilmuwan muslim yang memberi kontribusi besar dalam peradaban dunia. Zaman keemasan ini ditandai pertama kali dengan munculnya kelompok-kelompok aliran keilmuan yang pada saat itu lebih banyak berfokus pada filsafat ketuhanan atau tauhid.

Tidak mengherankan memang, jika pada zaman pertengahan bangsa muslim mengalami kemajuan yang pesat dalam bidang ilmu pengetahuan. Hal ini dapat dilacak dari sejarahnya, yakni adanya ekspansi kebudayaan yang dilakukan oleh Alexander Yang Agung. Usaha ini adalah untuk menyatukan dan mengenalkan kebudayaan Romawi Yunani ke dunia timur. Paham ini sering disebut dengan paham hellenistik. Usaha ini tampaknya cukup berhasil dilakukan oleh Alexander Agung, hal ini tampak dari kebudayaan Mesir, Persia, Bizantyum yang sedikit terpengaruhi kebudayaan Yunani Romawi. Merosotnya Kebudayaan Romawi Yunani juga di sebabkan jatuhnya pusat kebudayaan yakni Bizantyum ke tangan kaum Muslim. Inilah awal perkembangan kemajuan ilmu pengetahuan dunia Islam, Bizantyum atau Konstantinopel pada waktu direbut dan jatuh ke tangan muslim ialah merupakan satu-satunya pusat pewaris peradaban barat terutama Yunani Romawi. Pada masa inilah kaum Muslim mulai menerjemahkan kitab-kitab Yunani Romawi ke dalam bahasa Arab. Untuk dipelajari dan di kembangkan. Dan pada era inilah muncul Filsuf-filsuf Muslim yang sangat terkenal, seperti Al-Kindi, Ibnu Rusyd, Ibnu Sina, Al- Farabi dan masih banyak yang lain. Ilmuwan muslim ini tidak hanya pandai atau menguasai satu bidang keilmuan saja tetapi berbagai bidang. Ibnu Sina misalnya, tidak hanya sebagai filsuf, tetapi juga dikenal dengan bapak kedokteran. Ibnu Sina juga merupakan pemikir yang ahli dalam bidang kedokteran. Karyanya dalam bidang filsafat dan kedokteran masih dipakai sampai sekarang. Ibnu Rusyd yang 
mendapat julukan the comentator juga seorang filsuf. Komentar-komentar Ibnu Rusyd sangat detail terhadap karya Aristoteles, sehingga menjadi rujukan bagi orang yang ingin mempelajari filsafat Aristoteles.

\section{METODE PENELITIAN}

Guna memperoleh bahan-bahan yang berdaya guna bagi penyusunan konsep-konsep dan kerangka teoritis serta bahan kajian yang bernilai tentang filsafat dalam pandangan filsuf muslim, maka beberapa langkah atau tahap-tahap penelitian yang dilakukan, yaitu: Pertama, heuristik atau pengumpulan sumber. Kuntowijoyo (Kuntowijoyo, 1999: 12), mengatakan bahwa kebenaran sejarah terletak dalam kesediaan sejarawan untuk meneliti sumber sejarah secara tuntas, sehingga diharapkan akan dapat mengungkap sejarah secara tuntas. Oleh karena itu, pada tahap ini peneliti mencari data sebanyak-banyaknya, baik berupa buku, jurnal, ataupun arsip tentang pemikiran filsafat dalam pandangan muslim.

Langkah kedua, kritik sumber (verifikasi), dalam penyeleksian sumber perlu kritik ekstern yakni berkaitan dengan otentisitas atau keaslian sumber. Dengan kritik ekstern sumber tersebut dapat dipercaya keasliannya serta kritik internal yang berkaitan dengan masalah kredibilitas sumber atau kebenaran isi sumber tersebut. Sementara itu, kritik intern dalam penelitian ini dilakukan dengan membandingkan sejumlah sumber mengenai substansi persoalan yang sama, serta mengamati kaitan ilmiahnya dengan terminologiterminologi konseptual yang tersedia, dalam hal ini membandingkan sumbersumber buku dan jurnal yang diperoleh. Langkah ketiga ialah interpretasi, interpretasi merupakan penafsiran data-data yang telah diseleksi sebelumnya untuk mendapatkan fakta yang terkait dengan tema penelitian, baik dengan cara analisis (menguraikan) maupun sintesis (menyatukan). Analisis yang dilakukan ialah menguraikan data yang sekiranya satu sama lainnya saling berkaitan, kemudian disimpulkan untuk memperoleh fakta. Sementara sintesis mengelompokkan data dengan bantuan kerangka konseptual. Pada tahap ini erat kaitannya dengan ilmu-ilmu lain, ilmu sosial dan ilmu psikologi ataupun ilmu agama misalnya, hubungan ini perlu digunakan untuk mendapatkan fakta sejarah guna memudahkan penulisan yang berkenaan dengan tema penelitian yakni filsafat dalam pandangan filsuf muslim. Langkah keempat, historiografi, historiografi merupakan tahap atau langkah terakhir, yakni berupa penulisan sejarah. Penulisan ini disusun sesuai dengan alur dan cara berpikir peneliti serta pilihan peneliti untuk menguraikan pembahasan secara kronologis, sinkronik, ataupun diakronik. Tahap penulisan ini tentu tidak terlepas rekonstruksi yang imajinatif. Tahap ini peneliti mengorganisasikan dan mengemukakan penemuan-penemuannya yang didapatnya dalam bentuk karya sejarah, yakni filsafat dalam pandangan filsuf muslim, yang masuk dalam kategori sejarah pemikiran.

\section{HASIL PENELITIAN DAN \\ PEMBAHASAN}

\section{MUSLIM DAN FILSAFAT}

\subsection{Pengertian Filsafat}

Secara etimologis, kata "filsafat" merupakan padanan kata Falsafah dari bahasa arab dan philosophy dari bahasa Inggris, yang diambil dari bahasa Yunani Philosophia. Menurut Ali Maksum, Philosophia merupakan kata majemuk yakni dari kata Philos dan Sophia. Philos berarti cinta, atau sahabat sedangkan Sophia berarti 
kebijaksanaan, kearifan, dan pengetahuan. Sehingga secara etimologis filsafat berarti cinta kebijaksanaan, cinta kearifan, sahabat kebijaksanaan. ${ }^{1}$ Hal yang sama juga dikemukakan oleh Aripin Banasuru dalam bukunya Filsafat dan Filsafat Ilmu dari hakikat ke tanggung jawab mendefinisikan, Arifin mengatakan bahwa filsafat berasal dari kata Philosophy dalam bahasa Inggris, Falsafah dalam bahasa Arab, dan Philosophia dalam bahasa Yunani. Philosophia dalam bahasa Yunani berasal dari kata Philein yang berarti cinta dan Sophia yang berarti kebijaksanaan. Jadi Philosophia adalah cinta kebijaksanaan. ${ }^{2}$

Aristoteles mengemukakan bahwa filsafat ialah ilmu yang meliputi kebenaran yang terkandung di dalamnya ilmu-ilmu metafisika, logika, retorika, etika, ekonomi, politik, dan estetika. Selain itu Aristoteles mengatakan bahwa filsafat menyelidiki sebab dan asas segala terdalam dari wujud. ${ }^{3}$ Sementara itu Al-Farabi mengemukakan bahwa filsafat ialah ilmu tentang alam yang Maujud dan bertujuan menyelidiki hakikatnya yang sebenarnya. ${ }^{4}$ Sidi Gazalba mengemukakan bahwa Filsafat ialah berpikir secara mendalam, sistematik, radikal dan Universal dalam rangka mencari kebenaran, inti atau hakikat mengenal segala

1 Ali Maksum.2012. Pengantar Filsafat:Dari Masa Klasik hingga Postmodernisme, Cetakan ke VI. Jogjakarta: Ar-Ruzz Media. hal. 15-16.

${ }^{2}$ Aripin Banasuru.2013. Filsafat Dan

Flsafat Ilmu: Dari Hakekat Ke Tanggung Jawab. Bandung: Alfabeta. Hal 2.

${ }^{3}$ Amsal Baktiar. 2013. Filsafat Ilmu. Cet 13. Depok: Raja Grafindo Persada. Hal 7.

${ }^{4}$ Endang Saipudin Ashari. 1987. Ilmu, Filsafat, Agama Cet. VII. Surabaya: Bina Ilmu. Hal 83. sesuatu yang ada. ${ }^{5}$ Dalam definisi ini siti Gazalba mencoba untuk memberikan gambaran filsafat itu ialah berpikir tingkat tinggi, terarah dan punya metode. Pendapat Sidi Gazalba ini memperlihatkan adanya tiga ciri pokok dalam filsafat, yakni ${ }^{6}$ :

1. Adanya unsur berpikir yang dalam hal ini menggunakan akal.

2. Adanya unsur tujuan yang ingin dicapai melalui berpikir tersebut.

3. Adanya Unsur ciri yang terdapat dalam pikiran tersebut, yaitu mendalam.

Harold H. Titus menampilkan empat buah pengertian Filsafat ${ }^{7}$, yakni:

1. Filsafat ialah satu sikap tentang hidup dan tentang alam semesta.

2. Filsafat ialah satu metode pemikiran reflektif dan penyelidikan.

3. Filsafat ialah suatu perangkat masalah.

4. Filsafat ialah satu perangkat teori atau sistem pikiran.

Ajat Sudrajat dalam Bukunya mengatakan bahwa objek pemikiran filsafat adalah segala yang ada, yaitu tuhan, maka lahirlah filsafat ketuhanan. Jika yang menjadi objek adalah tentang manusia maka lahir filsafat manusia. jika yang menjadi objek ialah tentang alam, maka lahirlah filsafat kealaman. Intinya apabila terjadi suatu pemikiran secara rasional, kritis, sistematis, dan radikal terhadap suatu obyek

5 Sidi Gazalba. 1978. Asas Kebudayaan Islam. Jakarta: Bulan Bintang. Hal 316.

6 Abuddin Nata. 1999. Filsafat Pendidikan Islam. Jakarta: Logos Wacana Ilmu. Hal 3-4

7 Burhanudin Salam. 2012. Pengantar Filsafat. Jakarta: Bumi Aksara. Hal 68. 
tertentu maka pekerjaan tersebut dapat dikatakan sebagai berpikir filosofis atau bercorak kefilsafatan. ${ }^{8}$

\subsection{Masuknya Filsafat Ke Dunia Islam}

Seperti yang dikemukakan di awal bahwa untuk melacak masuknya ilmu pengetahuan ke dunia Islam perlu sedikit melacak jejak ilmu pengetahuan di Eropa atau barat terutama sejak abad pertengahan. Karena pada abad pertengahan dunia barat Eropa dan dunia Islam di timur sangat berbeda. Abad pertengahan di Eropa merupakan abad gelap, yakni abad di mana Eropa diselubungi dogma gereja yang mengekang ilmu pengetahuan. Lebih jauh lagi ilmu pengetahuan masuk ke dunia timur bisa dilacak jejaknya dari kisah hellenisme Alexander Agung ke dunia timur. Yakni kisah perjalanan Alexander agung menaklukkan dunia timur dan menyatukannya dengan melakukan penetrasi kebudayaan Yunani Romawi, tentu di dalamnya termasuk ilmu Pengetahuan.

Selama berabad-abad ilmu pengetahuan telah masuk ke dunia timur, terutama kawasan Jazirah Arab, Eropa Timur, dan daerah laut Kaspia, atau Turki sekarang. Setelah keberhasilan program Hellenisme oleh Alexander Agung, Eropa mengalami di mana masa-masa sulit yakni the dark age.di mana pusatpusat pengetahuan di hancurkan oleh kaum gereja. Sementara itu, Byzantium merupakan pusat studi satu-satunya yang masih tersisa dan pada suatu saat jatuh ke tangan muslim. Yang kemudian berganti nama menjadi Konstantinopel, yang kemudian dikenal dengan sebutan

8 Ajat Sudrajat.2015. Sejarah Pemikiran Dunia Islam dan Barat. Malang: Instrans Publishing. Hal. 55
Istambul. Pada masa inilah kaum muslim mulai berkenalan dengan ilmu pengetahuan Eropa terutama masa klasik yakni Yunani dan Romawi. Pada Periode inilah muncul ilmuwan-ilmuwan muslim yang ahli dalam berbagai bidang, seperti filsafat, kedokteran, astronomi, kimia. Kendati Islam telah dikenal sejak abad ketujuh tetapi perkembangan ilmu pengetahuan Islam baru muncul pada abad pertengahan. Hal ini karena pada zaman Rasulullah tidak ada ismeisme yang berkembang selain wahyu. Ilmu pengetahuan sendiri terutama filsafat baru berkembang pada abad IX hingga XII Mahesi. Salah satu kegemilangan dunia Islam ialah dikenalnya filsafat ini terutama selama Daulah Abbasiyah di Bagdad (750-1258) dan Daulah Amawiyah di Spanyol (755-1492).

Hal yang sama dikemukakan oleh Ajat Sudrajat, dikatakan bahwa Pemikiran Filosifis mulai tampak dari kalangan Islam ialah dimasa Daulah Abbasiyah. Mula-mula kaum muslim tertarik untuk mempelajari ilmu kedokteran, tetapi berlanjut ke bidang lainnya, termasuk Filsafat. Lebih lanjut Ajat Sudrajat menjelaskan bahwa Perhatian Muslim atau Islam terhadap Filsafat meningkat pada masa pemerintahan khalifah Al-Makmun (813-833M), AlMakmun merupakan putra Harun AlRasyid. Pada masa Pemerintahannya inilah banyak dikirim ilmuwan ke Bizantium untuk mempelajari ilmu dan mencari manuskrip untuk di terjemahkan ke dalam bahasa Arab. ${ }^{9}$ Al-Makmun kemudian mendirikan Bait al-hikmah di Bagdad sebagai bentuk keseriusan dalam menerjemahkan kitab-kitab bahasa Yunani dan Romawi. Lembaga

${ }^{9}$ Ibid. hal . 56 
ini pimpin oleh Hunain ibn ishaq yang merupakan seorang Kristen. Hunain dipercaya memimpin lembaga ini karena Hunain mengusai bahasa Yunani dan Siriak. Bukubuku yang banyak di terjemahkan ialah karya filosof Yunani zaman keemasan, yakni Plato, dan Aristoteles. Pada masa inilah muncul berbagai nama filsuf besar Islam .

\subsection{Periodisasi Keilmuan Muslim}

Perkembangan Islam terhadap ilmu pengetahuan pada abad pertengahan ini dapat dibagi dalam beberapa periode yakni sebagai berikut.

\subsubsection{Periode Kalam Pertama}

Periode kalam pertama ditandai dengan munculnya kelompok-kelompok

Mutakallimin/Aliran-aliran dalam ilmu kalam, yakni sebagai berikut. 1) aliran Khawarij, 2) Murjiah, 3) Qadariyah, 4) Jabariyah, 5) Mu'tazilah, 6) Ahlu Sunnah. Dari keenam aliran ini, yang berkaitan dengan filsafat ialah aliran Mu'tazilah. Pendirinya ialah Wasil bin Atha, Wasil di anggap sebagai Rasionalisme Islam. Dalam kaitannya dengan Filsafat Aliran Mu'tazilah memberikan ajaran yakni AlTauhid, Al-Iradah, Al- 'Adalah, Al-Manzilah bain AlManzilatain, Al-amr bi al-ma'ruf wa al nahy 'an al-munkar. Ajaran ini diberikan untuk memberikan jawaban atas paham-paham Khawarij yang teokratik. ${ }^{10}$

\subsubsection{Periode Filsafat Pertama dan} kedua

Periode ini ditandai dengan munculnya ilmuwanilmuwan dan ahli-ahli dalam berbagai bidang keilmuan, dan ilmuwan yang menaruh perhatian terhadap filsafat Yunani, terutama Aristoles dan Plato. Periode filsafat pertama ini, ditandai dengan munculnya filsuf muslim yang terkenal dari timur. Filsuf-filsuf yang muncul pada Periode pertama ini antara lain sebagai berikut. 1) Al-Kindi (806-873 M), 2) AlRazi (865-925 M), 3) Al- Farabi (870-950 M), 4) Ibn Sina (9801037).

Periode kalam kedua ialah munculnya kalangan tokoh muslim yang berpengaruh besar terhadap ilmu kalam. Tokoh-tokoh yang muncul dalam periode ini adalah AlAsy'ari ( 873-957 M) dan AlGhazali (1065-1111 M). Pada Periode ini Al-Ghazali mencoba mengkritik filsuf dengan bukunya Tahafut Al-Falasifah (Kerancuan Filsafat). Yang kemudian nanti akan dibantah oleh komentar-komentar Ibn Rusyd. Al-Asy'ari dulunya adalah pengikut aliran Mu'tazillah, tetapi karena tidak puas dengan ilmu yang didapat Al-Asy'ari keluar dari Mu'tazillah dan mendirikan aliran sendiri yakni aliran Asy'riyah. ${ }^{11}$

\subsubsection{Periode Filsafat Kedua}

Periode ini ditandai dengan munculnya sarjanasarjana dan ahli dalam berbagai bidang yang tentu saja juga menekuni bidang filsafat. Tokoh-tokoh filsafat abad kedua ini hidup di Spanyol yakni pada masa Daulah Amawiyah. Seperti di ketahui bahwa Eropa saat itu sedang

${ }^{10}$ Ali Maksum, op cit. hal 101.

${ }^{11}$ Maksum, Op cit. hal 102. 
tenggelam dengan apa yang disebut dengan abad gelap. Dengan tampilnya filsuf muslim di Spanyol ini maka menunjukkan bahwa ilmu pengetahuan Islam telah berkembang dengan baik. Filsuf-filsuf periode kedua ini adalah: 1) Ibnu Bajjah (11101113 M) yang di Eropa dikenal dengan nama Avempace, 2) Ibnu Thufail (m. 1185 M) yang dikenal di Eropa dengan nama Abubacer, 3) Ibnu Rusyd ( 1126-1198 M) yang dikenal dibarat dengan nama Averoce. Ibnu Rusyd pada masa ini mencoba meng counter pendapat Al-Ghazali dengan membuat sebuah buku yang berjudul Tahafut al-Tahafut (Kerancuan Kitab Tahafut).

Perlu diketahui bahwa sampai abad 12 orang Eropa belum mengenal filsafat Aristoles secara keseluruhan, baru setelah Ibnu Rusyd melakukan penjelajahan intelektual terhadap karya Aristoteleslah banyak orang Eropa yang mengenal Ariestoteles. Terutama setelah Ibnu Rusyd mengeluarkan karya-karyanya terhadap pemikiran Ariestoteles. ${ }^{12}$

\section{$\begin{array}{lll}\text { FILSUF } & \text { MUSLIM }\end{array}$ PANDANGANNYA}

Pergumulan dunia Islam dengan ilmu pengetahuan barat terutama Yunani, telah membuat dunia muslim menguasai dunia ilmu pengetahuan, termasuk di antaranya adalah filsafat. Zaman keemasan dunia Islam terhadap ilmu pengetahuan ini telah melahirkan filsuf-filsuf terkenal dan mempunyai pengaruh besar dalam peradaban

${ }^{12}$ Maksum, op cit. hal 104. dunia Islam dan Eropa. Di antara filsuf-filsuf muslim yang berpengaruh dari antara lain sebagai berikut.

\section{Al-Kindi (801-866 M)}

Sebenarnya Al-Kindi adalah nama nisbat dari sukunya yakni Banu Kindah. Nama lengkap AlKindi adalah Abu Yusuf Ya'qub Ibn Ishaq Ash-Shabbah ibn'Imran ibn Ismail ibn Al-Asy'ats Ibn Qays Al-Kindi. Al-Kindi Lahir di Kufah tahun 185H. Al-Kindi Merupakan satu-satunya Filsuf dari Arab sehingga mendapat julukan Failasuf Al-'Arab. Alkindi adalah Filsuf yang mempertemukan antara filsafat dan agama. Menurut Al-Kindi Antara Filsafat dan Agama tidak ada pertentangan. Filsafat adalah semulia-mulia ilmu dan ilmu tauhid atau teologi adalah cabang termulia dari filsafat. AlKindi mengatakan bahwa filsafat yang paling tinggi ialah filsafat yang berusaha mengetahui kebenaran yang pertama, kausa atau sebab semua kebenaran, yaitu apa yang disebut dengan filsafat pertama. ${ }^{13}$

Tentang metafisika Al Kindi berpendapat bahwa filsafat yang tertinggi adalah filsafat pertama atau Causa Prima. Al-Kindi Mengatakan bahwa Tuhan adalah Wujud Yang Haq (benar) dan tidak akan pernah tiada sebelumnya dan akan pernah ada selama-lamanya. Dalam hal ini Al-Kindi sependapat dengan Aristoltes tentang metafisika yakni tentang Causa Prima atau Penggerak Pertama. Tentang Pengetahuan, Alkindi mengatakan bahwa ada tiga macam pengetahuan manusia, Yaitu : 1) Pengetahuan inderawi,

${ }^{13}$ Ajat Sudrajat, op cit. hal 58. 
2) pengetahuan rasional, 3) pengetahuan Isyraqi (Illuminatif). Pengetahuan inderawi terjadi secara langsung ketika seseorang mengalami suatu obyek material. Pengetahuan bersifat tidak tetap karena obyek yang diamati pun tidak tetap. Pengetahuan Rasional, ialah pengetahuan yang diperoleh dengan jalan menggunakan akal yang bersifat universal, tidak parsial dan bersifat imaterial. Yang diamati bukanlah bentuk dari manusia itu, tetapi hakikatnya manusia itu sendiri, sehingga dapat disimpulkan bahwa manusia adalah makhluk berpikir (rational animal atau Hayawan al-natiq).

Pengetahuan Iluminatif, merupakan pengetahuan yang langsung dari pancaran Nur Ilahi. Jalan ini adalah yang diperoleh oleh para Nabi untuk membawakan ajaran yang berasal dari wahyu kepada umat manusia. orang yang mendapat Pancaran Ilahi adalah orang yang tidak biasa dan berusaha untuk mendapatkannya. Kalaupun adalah orang biasa yang mendapat pancaran Nur Ilahi ini, pasti di bawah Nabi dan jiwanya sudah Suci. ${ }^{14}$ Tentang Etika, al kindi berpendapat bahwa keutamaan manusiawi tidak lain adalah "budi Pekerti Manusia Yang Terpuji". Keutamaan ini ada tiga bagian yakni asas dalam jiwa ( hikmah, Najdah, Iffah), Keutamaan yang tidak terdapat dalam jiwa, keutamaan yang terakhir adalah keadilan.

2. Al-Farabi ( 872-950 M)
Abu Nasr Muhammad Ibn Muhammad ibn Tarkhan ibn Uzlagh Al-Farabi. Itulah nama lengkap dari filsuf besar Islam . Al -Farabi adalah putra seorang panglima perang Dinasti Samani. Al-Farabi lahir di Farab, daerah Persia, Al-Farabi adalah Keturunan Turki. Nama Al-Farabi di Nisbatkan dari asalnya yaitu Farab. Terkait dengan Filsafat dan agama, Al-Farabi satu pandangan dengan al-kindi, yakni tidak ada pertentangan antara Filsafat dan agama. Tetapi Al-Farabi menekankan bahwa filsafat harus di hindarkan dari orang awam, dikarenakan takut mengganggu keyakinan orang awam. ${ }^{15}$ Berkenaan dengan metafisika, Filsafat Emanasi adalah filsafat Al-Farabi tentang tuhan. Al-Farabi mengatakan bahwa segala yang ada atau alam ini memancar dar Zat Tuhan melalui Akal-akal yang berjumlah sepuluh. Tuhan berpikir tentang dirinya, sehingga muncul akal pertama, sehingga akal pertama berpikir hingga muncul akal kedua. Hingga sampai pada akal kesepuluh. Tentang Akal, AlFarabi mengatakan akal atau Daya berpikir ini mempunyai tiga tingkat, yaitu Al-'Aql Al-Hayulani ( akal material/ Akal Intelek), Al'aql bi al-fi'l (actual Intelec), Alaql al Mustafad (aquered intelec). Akal tingkat tiga inilah yang dapat menerima pancaran dari tuhan. Akal potensial menangkap bentuk-bentuk dari benda yang dapat ditangkap dengan panca indera. Akal actual menangkap arti dari konsepkonsep. Sementara itu akal mustafad ialah akal untuk

${ }^{15}$ Ajat Sudrajat, op cit. hal 60.

${ }^{14}$ Ajat Sudrajat, op cit. hal 59. 
mengadakan komunikasi dengan atau menangkap inspirasi dari akal yang ada dari luar diri manusia. ${ }^{16}$

Tentang Filsafat Kenabian, ialah yang menarik dari filsuf muslim dan filsafat Islam . Adalah filsafat kenabian. Yang coba di tawarkan oleh Al-Farabi. Nabi dan Rasul dapat menerima dan menangkap wahyu karena mampu untuk berkomunikasi dengan akal yang kesepuluh. Akal kesepuluh ini dapat disamakan dengan malaikat dalam pandangan Islam . Nabi dan Rasul adalah Manusia pilihan, dan dapat berkomunikasi dengan akal kesepuluh melalui izin tuhan. Sementara itu M. Subhi mengatakan bahwa Filsafat Kenabian yang diciptakan oleh Al-farabi adalah untuk menentang pendapat tentang tidak perlunya nabi oleh sebagian filsuf, salah satunya adalah Al-Razi. Al-Farabi mengatakan bahwa nabi adalah seorang yang dianugerahi bakat intelektual luar biasa sehingga dengan bakat tersebut, ia mampu mengetahui sendiri semua hal tanpa bantuan pengajaran sumber-sumber eksternal. ${ }^{17}$

\section{Ibn Sina (980-1037 M)}

Abu 'Ali Husein ibn Abdillah ibn Sina, itulah nama lengkap Ibnu Sina. Orang tuanya adalah pegawai tinggi Dinasti Samani. Oleh kalangan filsuf barat, Ibnu Sina dikenal dengan nama Avicenna. Dalam dunia Islam Ibnu Sina disebut sebagai Al-

${ }^{16}$ Ajat Sudrajat, op cit. hal 61.

17 M. Subhi.2012. Serial Tokoh Pemikiran Islam (Al-Farabi: Sang Perintis Logika Islam). Jakarta: Dian Rakyat. Hal. 62.
Syaikh Al-Rais ( pemimpin utama dari para Filosof). Dalam pandangannya tentang tuhan dan kejadian alam, pandangannya sama dengan pandangan AlFarabi yakni Filsafat Emanasi, yakni adanya sinar dari Tuhan yang memancar ke akal pertama dan hingga ke akal yang kesepuluh, yakni malaikat Jibril. Tentang Jiwa, Ibnu Sina mengatakan bahwa jiwa manusia yang memancar dari akal kesepuluh. Ibnu Sina membagi Akal Kesepuluh menjadi tiga bagian yakni: Jiwa Tumbuhan ( al-Nafs AlNabatiyah) meliputi daya makan, daya tumbuh, dan daya berkembang biak. Jiwa Binatang (al-Nafs Al- Hayawaniyah) meliputi daya gerak dan daya menangkap, dalam hal ini menangkap lewat indra, representasi, dan imajinasi.

Sementara itu tentang Filsafat Kenabian, Ibnu Sina mengatakan bahwa manusia ada yang dianugerahi akal materiil (al-Aql Al-Hayulani) yang begitu besar dan kuat yang disebut dengan intuisi. Orang yang punya akal tersebut tanpa latihan langsung bisa berkomunikasi dengan akal yang ksepuluh atau dapat langsung menerima cahaya atau wahyu dari tuhan. Akal ini oleh Ibnu Sina disebut dengan (quwwah Qudsiyah ) atau akal daya suci. Inilah akal tertinggi yang dapat dicapai manusia, yakni akal yang dapat diperoleh oleh para nabi. ${ }^{18}$

\section{Ibn Miskawaih ( 932-1030 M)}

Terlahir dengan nama lengkap $\mathrm{Abu}$ 'Ali Al-Khazim 
Ahmad ibn Muhammad ibn Y'qub Miskawaih. Ibn Miskawaih lahir di Teheren Iran. Bekerja sebagai Pustakawan. Dalam bidang filsafat Ibnu Miskawaih lebih banyak memfokuskan pada Filsafat Ahlak. Salah satu karyanya dibidang Filsafat ialah Tahzib Al-Akhlaq. Tentang Jiwa, Ibnu Miskawaih mengatakan bahwa ada tiga kekuatan jiwa yaitu : a), Bahimiyah atau syahwiyah (kebinatangan atau nafsu syahwat) jiwa yang senantiasa mengejar Kelezatan Jasmani, b) Sabu'iyah (binatang buas) jiwa yang bertumpu pada kemarahan dan keberanian, c) Nathiqah (berpikir) jiwa yang selalu berpikir tentang hakikat segala sesuatu. Jika ingin mendapatkan keutamaan dan kebajikan maka ketiganya harus selaras dan seimbang.

Terkait dengan Cinta, Ibnu Miskawaih mengatakan ada dua Jenis Cinta. Yakni cinta kepada Allah dan cinta kepada manusia. Cinta yang nilainya tinggi adalah Cinta Kepada Allah. Hanya saja cinta ini hanya dapat dicapai oleh sedikit orang. Cinta kepada manusia adalah cinta anak kepada orang tuanya dan cinta murid kepada Gurunya. Tentang pendidikan anak, Ibnu Miskawaih mengatakan bahwa ada dua syarat untuk kehidupan utama anak, yakni syarat Kejiwaan dan syarat Sosial. Syarat Kejiwaan adalah Syarat untuk membentuk anak tentang cinta pada kebaikan. Dan syarat Sosial adalah dengan memilih teman yang baik dan berperangai baik pula. 19

5. Al- Razi ( 863-925 M)
Abu Bakar Muhammad Ibn Zakaria Al-Razi lahir di Raily Teheran. Al-Razi dikenal dengan bapak Kedokteran, karena bekerja pada sebuah Rumah sakit dan banyak menelurkan tulisan tentang penyakit. Di barat AlRazi dikenal dengan Rhazes. Dalam bidang Filsafat ialah adalah seorang Rasionalis Sejati. Dalam bidang agama dan akal misalnya. Razi lebih percaya kekuatan akal, dan tidak percaya pada wahyu dan perlunya para nabi. Menurutnya Akal manusia sanggup untuk membedakan mana baik dan mana buruk. Oleh karena pahamnya yang tidak percaya nabi inilah, sebagai Antitesis, Al-Farabi Menciptakan Filsafat Kenabian. Hal ini dimaksudkan untuk Mengkounter paham Al-Razi. Kaitannya hubungannya manusia dengan tuhan, Al-Razi berpendapat bahwa kesenangan manusia sebenarnya ialah kembali kepada tuhan dengan meninggalkan Alam Materi. Untuk kembali kepada tuhan roh manusia harus disuci terlebih dahulu. Dan yang dapat menyucikan adalah ilmu pengetahuan dan berpantang yang mengerjakan yang tidak baik. $^{20}$

Al-Razi juga mengemukakan Filsafat Lima Kekal. Menurutnya ada lima Hal yang Kekal dalam kehidupan ini, yaitu: Tuhan, Jiwa Universal, Materi Pertama, Ruang Absolut, dan Zaman Absolut. Kelima kekal itu dijelaskan bahwa Materi, Merupakan apa yang ditangkap dengan panca indera tentang benda itu. Ruang, Karena materi itu ada tempat.

${ }^{20}$ Op cit. hal 66.

${ }^{19}$ Op cit. hal 64. 
Zaman, karena materi berubahubah keadaannya. Al-Razi juga mengatakan perlu adanya Roh, untuk benda-benda hidup. Untuk mewujudkan benda hidup itu perlu ada akal, akan benda hidup tersebut dapat teratur. Dan semuanya ini perlu pencipta yang bijaksana dan maha tahu.

\section{Ibn Rusyd (1126-1198 M)}

Abu al-Walid Muhammad ibn Muhammad ibn Rusyd itulah nama lengkapnya. Ibnu Rusyd memiliki latar belakang keluarga hakim di Andalusia. Ibnu Rusyd Sendiri tercatat pernah menjadi hakim di Seville. Tentang Filsafat dan Agama, Ibnu Rusyd memiliki pandangan, Filsafat tidak bertentangan dengan agama. Dalam hal ini Ibnu Rusyd menganjurkan untuk setiap muslim belajar dan tahu Filsafat. Ibnu Rusyd mengatakan bahwa tujuan filsafat adalah untuk mengetahui pencipta dari segala yang ada, atau untuk mengetahui tuhan. Ibnu Rusyd mengatakan, Bahwa setiap Muslim mesti percaya pada tiga dasar keagamaan, yakni Tuhan, Nabi dan Rasul, dan hari kebangkitan. Yang menarik dari ibnu Rusyd adalah pembelaannya terhadap Filsuf dari serangan Al-Ghazali, yang Mengatakan Filsuf adalah Kafir. Ini tertuang dalam bukunya Al-Ghazali yakni Tahafud al Falsafah. Serangan ini di counter oleh Ibnu Rusyd dengan bukunya Tahafud al Tahafud. Tentang kekekalan alam. Inbu Rusyd berpendapat bahwa alam diciptakan dari yang ada. oleh Ibnu Rusyd, beberapa ayat Al-Qur'an Dijadikan Rujukan Seperti Surat Al-Anbiya:30. Tentang tuhan, Ibnu Rusyd Mengatakan bahwa Pengetahuan tuhan tentang perincian terjadinya alam, tidaklah sama dengan pengetahuan manusia tentang perincian itu. Manusia hanya mengambil Efek, sedangkan tuhan merupakan sebab.

Kemudian tentang adanya pembangkitan jasmani. Kaum Filosof berpendapat bahwa pembangkitan jasmani itu tidak ada, maka tidak perlu dipertentangkan. Ibnu Rusyd mengatakan, belum ada ijma' tentang itu. Maka tidak ada yang kafir. Dan pendapat Al-Ghazali yang mengkafirkan filsuf tidaklah dibenarkan. Ibnu Rusyd mengatakan bahwa untuk menguatkan ke-Islam an orang awam, maka penggambaran pembangkitan jasmani diperlukan. ${ }^{21}$ Kosmologi adalah cabang filsafat metafisika khusus yang membahas dan mengkaji tentang hakikat alam semesta (cosmos) dan menyingkap tentang hakikat eksistensialnya yang tersembunyi dibalik fisiknya. Kosmologi membahas secara kefilsafatan tentang halhal yang berkaitan dengan eksistensi alam, Asalnya, dan tujuannya, bagaimana ia terjadi, bagaimana berevolusi, bagaimana susunannya, dan lain-lain. Dalam hal ini Ibnu Rusyd mengatakan bahwa alam (cosmos) diciptakan dari sesuatu yang sudah ada, yakni dari Alma'dan Al-dukhan. Penciptaan alam menurut Ibnu Rusyd berlangsung secara terus menerus sejak Azali atau dari sesuatu yang sudah ada. ${ }^{22}$

${ }^{21}$ Op cit. hal. 69.

${ }^{22}$ Fuad Mahbub Siraj. 2012. Serial Tokoh Pemikiran Islam (Ibn Rusyd: 


\section{KESIMPULAN}

Islam mengenal tradisi keilmuan sejak zaman kenabian. Setelah itu muncul kelompok-kelompok aliran pemikiran yang bersifat teologis, seperti Mutzaziilah dan Al Khawarijh. filsafat modern oleh dunia muslim baru dikenal setelah jatuhnya Konstanitonepel atau Bizantyum ke tangan muslim. Dari sinilah awal perkenalan dan pergumulan kaum muslim mencari dan mempelajari ilmu pengetahuan barat khususnya filsafat. Abad Gelap di Eropa, berbanding terbalik dengan di dunia Islam. Di mana Dunia Islam sedang dalam masa keemasan dunia ilmu Pengetahuan, termasuk Filsafat. Banyak muncul pada abad pertengahan ini Filsuf-Filsuf muslim yang ahli dalam berbagai bidang Ilmu Pengetahuan. Beberapa Ilmuwan dan filsuf Islam yang mempunyai nama besar adalah, Al-Kindi, Ibnu Sina, Ibn Rusyd, Al-Farabi, dan masih banyak yang lain. Mereka yang disebutkan ini, turut menyumbangkan kesuksesan terhadap ilmu pengetahuan Eropa Modern. Karya-karya filsuf muslim ini menjadi rujukan bagi filsuf Eropa masa renaisans untuk mempelajari karya filsuf ini dan menerjemahkan karya mereka ke dalam berbagai bahasa. Filsuf Eropa yang boleh dibilang menguasai filsafat Aristoteles, juga menggunakan karya Ibnu Rusyd sebagai rujukan, karena karya Ibnu Rusyd lah yang paling detail mempelajari dan membahas filsafat Aristoteles.

\section{DAFTAR PUSTAKA}

Abuddin Nata. 1999. Filsafat Pendidikan Islam. Jakarta: Logos Wacana Ilmu.
Ajat Sudrajat.2015. Sejarah Pemikiran Dunia Islam dan Barat. Malang: Instrans Publishing.

Ali Maksum. 2012. Pengantar Filsafat:Dari Masa Klasik hingga Postmodernisme, Cetakan ke VI. Jogjakarta: Ar-Ruzz Media.

Amsal Baktiar. 2013. Filsafat Ilmu. Cet 13. Depok: Raja Grafindo Persada.

Aripin Banasuru.2013. Filsafat Dan Flsafat Ilmu: Dari Hakekat Ke Tanggung Jawab. Bandung: Alfabeta.

Burhanudin Salam. 2012. Pengantar Filsafat. Jakarta: Bumi Aksara.

Endang Saipudin Ashari. 1987. Ilmu, Filsafat, Agama Cet. VII. Surabaya: Bina Ilmu.

Fuad Mahbub Siraj. 2012. Serial Tokoh Pemikiran Islam ( Ibn Rusyd: Cahaya Islam Di Barat). Jakarta: Dian Rakyat

Kuntowijoyo.1999. Pengantar Ilmu Sejarah. Yogyakarta: Bentang.

M. Subhi.2012. Serial Tokoh Pemikiran Islam ( Al-Farabi: Sang Perintis Logika Islam). Jakarta: Dian Rakyat

Sidi Gazalba. 1978. Asas Kebudayaan Islam. Jakarta: Bulan Bintang.

Cahaya Islam Di Barat). Jakarta: Dian Rakyat. Hal 75. 